УДК 612.821

https://doi.org/10.17816/MAJ19075

\title{
ANTIDEPRESSANT-LIKE ACTION OF HYPOXIC POSTCONDITIONING IS ACCOMPANIED BY THE UP-REGULATION OF HIPPOCAMPAL HIF-1 $\alpha$ AND ERYTHROPOIETIN
}

\author{
M.Yu. Zenko, E.A. Rybnikova \\ Pavlov Institute of Physiology RAS, Saint Petersburg, Russia
}

For citation: Zenko MYu, Rybnikova EA. Antidepressant-like action of hypoxic postconditioning is accompanied by the up-regulation of hippocampal HIF-1 $\alpha$ and erythropoietin. Medical Academic Journal. 2019;19(4):41-46. https://doi.org/10.17816/MAJ19075

Received: October 31, $2019 \quad$ Revised: November 14, 2019

Accepted: November 27, 2019

Objective. The aim of the study was to reveal the role of HIF-1 $\alpha$ in the effects of hypoxic postconditioning in the rat experimental model of depression "learned helplessness".

Materials and methods. The studies were performed in the "learned helplessness" paradigm which represents a reliable experimental model of depression in rats. The development of the pathology was evaluated in the behavioral open field test and by the baseline level of plasma corticosterone. Correction of behavioral deficit was performed by three episodes of hypoxic postconditioning $(360 \mathrm{mmHg}, 2 \mathrm{~h})$. Changes in the immunopositivity of HIF-1 $\alpha$ and erythropoietin in the hippocampus of rats were evaluated. An inhibitor of HIF-1 $\alpha$ subunit translation topotecan $\left(1 \mathrm{mg} / \mathrm{kg}\right.$, i.p., Santa Cruz, USA) was used on the $4^{\text {th }}$ day after the footshock stress. On the $9^{\text {th }}$ day, animals were tested in the open field test to assess the level of depressive-like behavior.

Results. It was shown that postconditioning by three episodes of mild hypobaric hypoxia resulted in the correction of behavioral deficit produced by the "learned helplessness" aversive stress, and the levels of corticosterone did not differ from the baseline in these animals. These behavioral and hormonal effects were accompanied by the increased level of immunopositive HIF- $1 \alpha$ and its transcriptional downstream target erythropoietin in the dorsal and ventral hippocampus. Using of HIF-1 inhibitor topotecan dramatically worsen the severity of the depressive-like symptoms.

Conclusion. The findings suggest that HIF-1 appears to have the antidepressant-like activities and that hypoxic postconditioning-induced stimulation of HIF-1 $\alpha$ and erythropoietin level might contribute to the endogenous mechanisms which compensate for the pathogenic effects of stressors, particularly for the development of stressinduced depression.

Keywords: depression; hypoxic postconditioning; stress-protective effect; learned helplessness; HIF-1 $\alpha$; erythropoietin.

\section{ВОВАЕЧЕНИЕ НIF-1 $\alpha$ И ЭРИТРОПОЭТИНА В АНТИАЕПРЕССИВНЫЙ ЭФФЕКТ ГИПОКСИЧЕСКОГО ПОСТКОНАИЦИОНИРОВАНИЯ В МОАЕАИ ВЫУЧЕННОЙ БЕСПОМОЩНОСТИ У КРЫС}

\author{
М.Ю. Зенько, Е.А. Рыбникова
}

ФГБНУ «Институт физиологии им. И.П. Павлова» РАН, Санкт-Петербург

Для цитирования: Зенько М.Ю., Рыбникова Е.А. Вовлечение HIF-1 $\alpha$ и эритропоэтина в антидепрессивный эффект гипоксического посткондиционирования в модели выученной беспомощности у крыс // Медицинский академический журнал. - 2019. - Т. 19. № 4. - C. 41-46. https://doi.org/10.17816/MAJ19075

Поступила: 31.10 .2019

Одобрена: 14.11 .2019

Принята: 27.11.2019

Цель исследования - оценить роль НIF-1 $\alpha$ в антидепрессивных эффектах гипоксического посткондиционирования в экспериментальной модели депрессии «выученная беспомощность» у крыс.

Материалы и методы. Исследования проведены в модели депрессивноподобного расстройства «выученная беспомощность» на крысах. Развитие патологии оценивали в поведенческом тесте «открытое поле», а также по базальному уровню кортикостерона в плазме крови крыс. Поведенческие нарушения корректировали путем применения трехкратного гипоксического посткондиционирования (360 мм рт. ст., 2 ч). Изменение иммунопозитивности HIF-1 $\alpha$ и эритропоэтина в гиппокампе крыс исследовали количественным иммуногистохимическим методом. Ингибитор трансляции HIF-1 $\alpha$ топотекан (1 мг/кг, внутрибрюшинно, Santa Cruz, CША) вводили на 4-й день после стресса, депрессивноподобное поведение крыс оценивали на 9-й постстрессорный день.

\section{List of abbreviations}

AKT/PKB - protein kinase B; BDNF - brain-derived neurotrophic factor; CRH - corticotropin-releasing hormone; DG - dentate gyrus; EPO - erythropoietin; GLUT1 - glucose transporter-1; HIF-1 $\alpha$ - hypoxia-inducible factor 1-alpha; HPA - hypothalamicpituitary-adrenal axis; HPostC - hypobaric hypoxic postconditioning; LH - learned helplessness; MAPK - mitogen-activated protein kinase; PI3K - phosphoinositide 3-kinases; VEGF - vascular endothelial growth factor. 
Pезультаты. Показано, что посткондиционирование, осуществленное за три сеанса умеренной гипобарической гипоксии, приводило к коррекции поведенческого дефицита и уровня кортикостерона в крови у крыс в данной модели, что сопровождалось повышением количества HIF-1 $\alpha$ и эритропоэтина в дорзальном и вентральном гиппокампе. Введение ингибитора HIF- $1 \alpha$ крысам усиливало поведенческие проявления «выученной беспомощности» в тесте «открытое поле».

Заключение. Представлены экспериментальные данные, свидетельствующие о вероятном вовлечении HIF-1 и эритропоэтина в эндогенные процессы компенсации патогенного действия стрессоров психоэмоциональной природы и антидепрессивные эффекты гипоксического посткондиционирования.

Ключевые слова: депрессия; гипоксическое посткондиционирование; стресс-протективное действие; выученная беспомощность; HIF-1 $\alpha$; эритропоэтин.

\section{Introduction}

In the early 2000 s, the original technique of hypoxic preconditioning has been elaborated in our laboratory. It was found that the preconditioning by using three episodes of mild hypobaric hypoxia produced in barochamber remarkably increased resistance of the brain and body to injurious exposures, such as severe hypoxia or psychoemotional stresses [1]. Afterwards, the same exposition was successfully applied not as a preventive strategy but as a corrective tool in rats survived severe injurious event, either of hypoxic or stress nature. This novel original method was termed hypobaric hypoxic postconditioning (HPostC) [2]. The applications of HPostC considerably improved recovery from the severe hypoxic insult and attenuated posthypoxic neuronal injury, reducing pyknosis, hyperchromatosis, and interstitial brain edema, as well as the rates of neuronal loss in vulnerable brain regions [3]. In addition, HPostC exerted a potent anxiolytic effect in stress-related models. Our Polish colleagues also reported that HPostC reduced brain damage and improved antioxidative defense in the rat model of birth asphyxia [4]. HPostC had a beneficial effect on the functioning of the hypothalamic-pituitary-adrenal axis (HPA), modifying its baseline tone and reactivity to stressors [3]. The apoptosis-related processes and neurotrophins (BDNF) have been identified as the endogenous mechanistic targets for the compensatory effects of HPostC in the post-hypoxic pathology [5], but the key roles have been ascribed to the hypoxia-inducible factor HIF-1. In particular, HPostC enhanced the expression of HIF- $1 \alpha$ and its main transcriptional target erythropoietin (EPO) in the hippocampal CA1 neurons of rats survived severe hypoxia [6]. Our recent data suggest that an important neuroprotective mechanism enabled by HPostC involves stabilization of the antioxidant system via HIF-1-dependent regulation of the pentose phosphate pathway [7]. The fact was discovered in the model of hypoxic injury and the question whether HIF-1 plays the same role in the non-hypoxic models remains open. Although the antioxidant defenses are not crucially important for the protection from psychoemotional stress, we hypothesize that HIF-1 might also significantly contribute to the beneficial effects of HPostC in the models of post-stress pathologies, in particular in stress-induced depression. Main argument for such suggestion relies upon the facts indicating tight functional interaction between HIF-1 and important components of stress response, such as glucocorticoid receptors [8]. The main HIF-1 target EPO also has a broad spectrum of protective actions in the brain [9-11]. In addition to direct neuroprotective properties, EPO is able to inhibit basal and stimulated corticotropinreleasing hormone $(\mathrm{CRH})$ release from the rat hypothalamus [12]. It is probable that in certain pathological conditions EPO may control the HPA axis function, preventing possible detrimental effects of HPA overactivation. Taken together, these evidences indicate a possible close interaction of specific factors mediating an adaptation to hypoxia and the neuroendocrine mechanisms of stress reactions. From a practical point of view, this opens up new prospects for the treatment of stress-induced depressions, but the issue requires detailed study.

To further examine the hypothesis, present study has been aimed in the analysis of HPostC effects, level of HIF-1 $\alpha$, and its target EPO in the rat model of stress-induced depression. The expression of HIF- $\alpha$ and EPO is examined in the hippocampus which has a central position in the neuroendocrine circuits of HPA feedback regulation.

\section{Materials and methods}

The experiments were carried out on the Wistar rats from the resources of the SF "Pavlov Institute Biocollection Centre". Rats with a body weight of $200-250 \mathrm{~g}$ were divided into equal groups $(n=12)$ and, except control group, were subjected to the footshock stress in the paradigm of the "learned helplessness" (LH), leading to the development of a depressive-like state [13]. Animals received a series of uncontrollable footshocks $(1 \mathrm{~mA}, 1 \mathrm{~Hz}$, 15 s) using a conductive cage floor; intervals of different duration were applied between the supply of current so that each rat received 60 stimulations within an hour. Footshock stress led to the formation of delayed persistent depressive-like state, which was previously confirmed by classical behav-

Tom
Volume

Bыпуск
Issue

2019

ISSN 1608-4101 (Print) 
ioral methods and functional tests for hypothalamic-pituitary-adrenal axis reactivity [14]. In order to correct pathology in animals of the second group, HPostC was used according to the original scheme, which had previously proven its effectiveness in the model of post-traumatic stress disorder in rats [3]. HPostC was performed using a three-time exposure to moderate hypobaric hypoxia $(360 \mathrm{~mm} \mathrm{Hg}, 2 \mathrm{~h}$ ) in the barochamber with a 24-hour interval, in the first three days after the footshock stress. The animals of the third group were intact control.

The development of depressive-like state, as well as the antidepressant effect of HPostC, was evaluated on the $5^{\text {th }}$ day by the open field behavioral test [15]. On the $6^{\text {th }}$ day after footshock stress all animals were decapitated, brain was quickly removed, hippocampal areas were isolated. Blood samples were centrifuged at $+4{ }^{\circ} \mathrm{C}$ for 10 minutes at $1000 \mathrm{~g}$, the plasma was stored at $-20^{\circ} \mathrm{C}$ until the determination of corticosterone level by the ELISA rats kit (Chema, Russia). Brain tissue samples were fixed with $4 \%$ paraformaldehyde solution, and then were subjected to standard procedures of washing, dehydration in alcohols, clarification in xylene and filling in paraffin blocks. Then, a series of alternating brain sections in the frontal plane with a thickness of 7 microns was made with the microtome. Changes in the HIF- $1 \alpha$ and erythropoietin immunopositivity in the dorsal (CA1) and ventral (dentate gyrus, DG) hippocampus were investigated by quantitative immunohistochemistry in brain sections. For this purpose, after the procedures of dewaxing, rehydration and demasking of the antigen, the slices were incubated during the night at $+4{ }^{\circ} \mathrm{C}$ with primary polyclonal rabbit antibodies to HIF-1 $\alpha$ (Santa Cruz, USA, dil. $1: 100$ ) and erythropoietin (Santa Cruz, USA, dil. 1:100), followed by avidine-biotin detection system (Vector Laboratories, Inc., UK) and diaminobenzidine visualization. Quantitative analysis of neuronal immunopositivity was carried out using a microimage analysis system consisting of the microscope Olympus CX31RBSF (Optical systems, Germany), the digital camera ProgResCT1 (Jenoptik, Germany) and the VideoTest Morphology 5.2 software (VideoTest, St. Petersburg). The number of immunopositive cells in the CA1 field of the hippocampus and the DG (400 microns long) was calculated at $-2.80 \mathrm{~mm}$ from the bregma. Based on the assessment of optical density, immunopositive cells were divided into two classes: the total number of immunopositive cells $(\mathrm{N})$ and the number of intensively immunopositive cells $(\mathrm{Ni})$ were determined.

In order to substantiate possible antidepressantlike role of HIF-1, an inhibitor of HIF-1 $\alpha$ subunit translation topotecan $(1 \mathrm{mg} / \mathrm{kg}$, i.p., Santa Cruz, USA), was used on the $4^{\text {th }}$ day after the footshock stress. On the $9^{\text {th }}$ day, animals were tested in an open field test to assess the level of depressive-like behavior.

Statistical analysis was performed using MannWhitney $U$-test (Statistica 10.0, Stat-Soft Inc.). Differences between samples were considered statistically significant at $p \leq 0.05$.

\section{Results}

The exposure of rats to inescapable and uncontrollable footshock in the "learned helplessness" paradigm induced development of the persistent depressive-like state appeared as drastically reduced locomotor activity (Fig. 1, $a$ ) and increased anxiety level and freezing time. The animals also had significant, more than two-fold elevation of the plasma corticosterone levels indicating severe HPA hyperactivity specific for such pathology as the depression (Fig. 1, b) Application of the HPostC to stressed rats abolished development of post-stress depressive-like state, compensating for the all pathologic symptoms. No side-effects for the HPostC were detected.

The antidepressant-like action of the HPostC appeared in parallel with considerable up-regulation of the HIF- $1 \alpha$ and EPO levels in the hippocampus. Remarkable increase in HIF- $1 \alpha$ and EPO levels was seen both in the dorsal (CA1 field) and ventral (dentate gyrus, DG) hippocampus of the HPostC rats. A quantitative analysis revealed that the amount of intensely labeled HIF- $1 \alpha$-positive cells (Ni) increased up to $2500 \pm 816 \%$ of control in the DG, whereas in CA1 their increase amounted only to $608 \pm 248 \%$ (Fig. $2, a, b$ ).
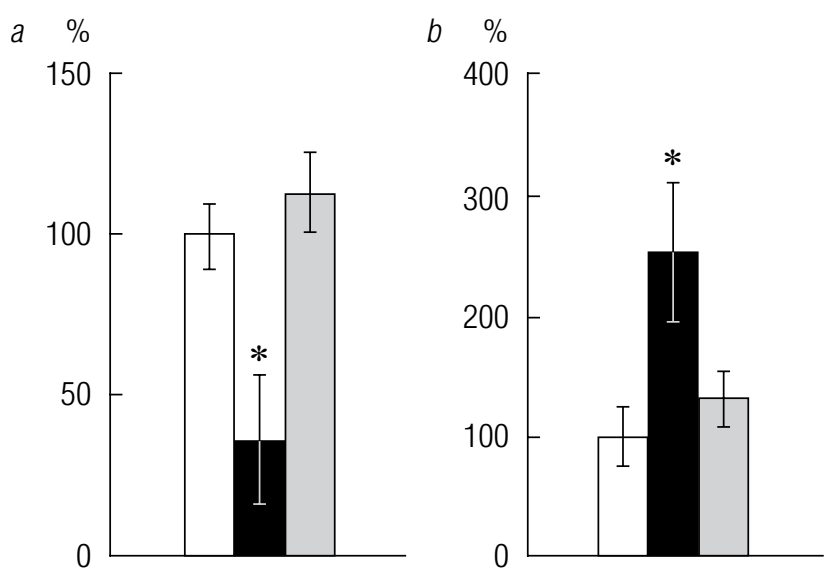

Fig. 1. Behavioral and hormonal effects of the hypoxic postconditioning in the rat model of depression: $a-$ horizontal locomotor activity in the open field test; $b-$ blood corticosterone level of different rat groups. Data are presented as a percentage of control values. White bars - control group, $100 \%(n=12)$, black bars - learned helplessness group $(n=12)$, gray bars - learned helplessness + HPostC group $(n=12)$. * statistically significant difference, $p \leq 0.05$, Mann-Whitney $U$-test 

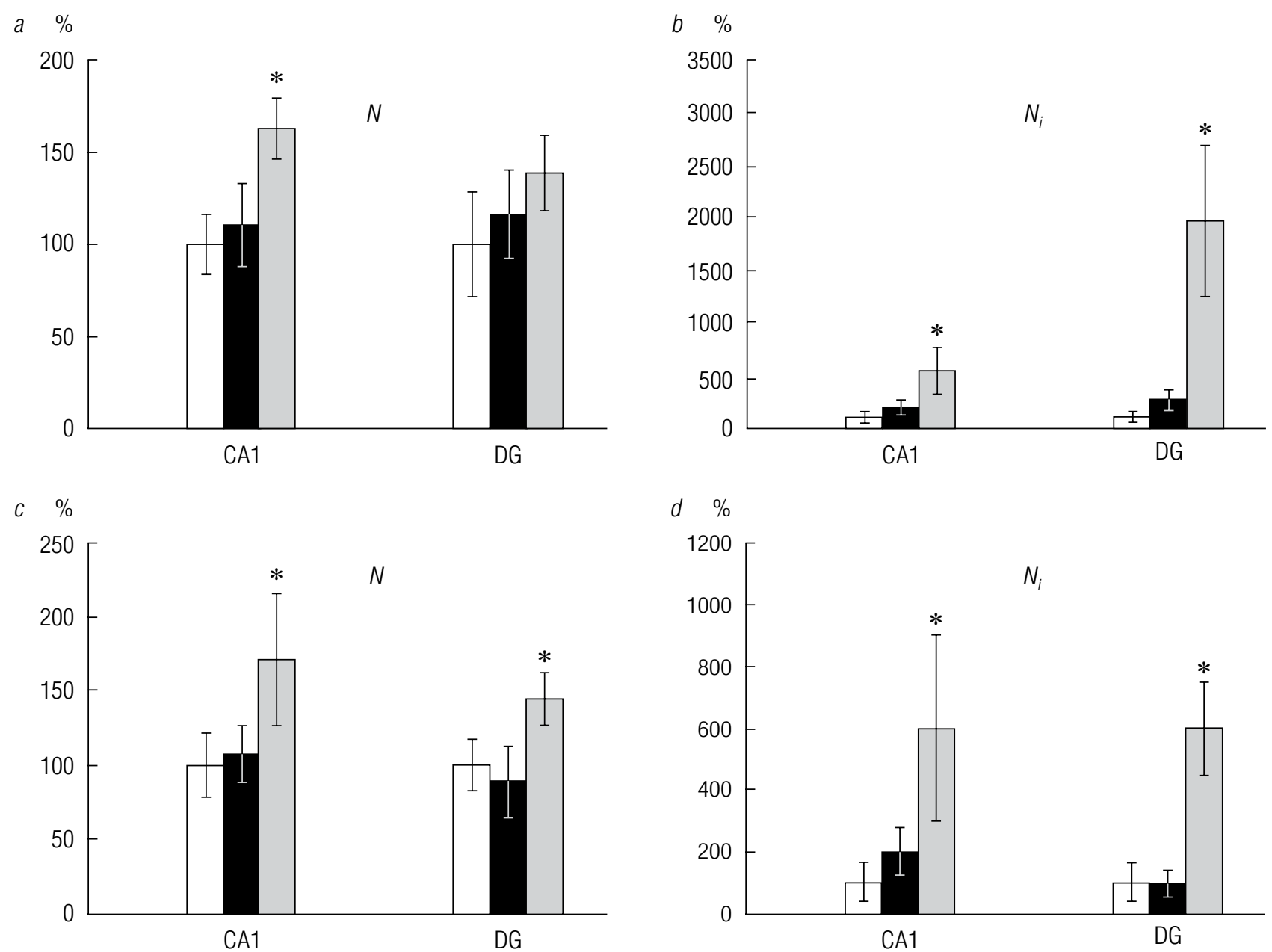

Fig. 2. Changes in the hippocampal level of HIF-1 $\alpha$ and EPO. Total number (N) and intensely labeled (Ni) immunopositive cells to $\operatorname{HIF}-1 \alpha(a, b)$ and erythropoietin $(c, d)$ in the CA1 and DG regions of the different experimental group rat hippocampus, $\%$ of the values in the control group. White bars - control group, $100 \%(n=12)$, black bars - learned helplessness group $(n=12)$, gray bars - learned helplessness + HPostC group $(n=12) .{ }^{*}$ statistically significant difference, $p \leq 0.05$, Mann-Whitney $U$-test

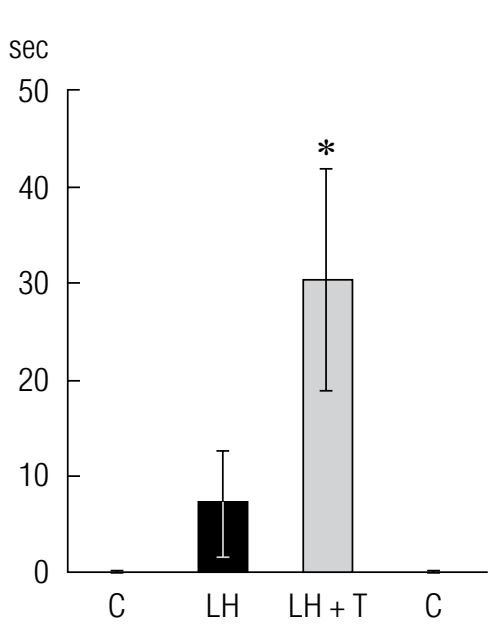

Fig. 3. The effect of topotecan (T) on the depressive-like behavior of rats in the open field (duration of freezing reactions, sec). The first bar - control group, $(n=6)$, black bar - learned helplessness group $(n=6)$, gray bar learned helplessness + topotecan group $(n=6)$, the fourth bar - topotecan group, $(n=6)$, *statistically significant difference, $p \leq 0.05$, Mann-Whitney $U$-test
Changes in the total number of the HIF-1 $\alpha$ immunopositive cells $(\mathrm{N})$ were comparatively less notable. In general, the data indicate that the upregulation of HIF- $1 \alpha$ was more than four times stronger in the dorsal hippocampus compared to the ventral one. Regarding EPO, both the total number $(\mathrm{N})$ and amount of intensely labeled $(\mathrm{Ni})$ EPO-immunopositive cells were increased remarkably (Fig. 2, $c, d$ ). In the LH group, the immunopositivity both to HIF- $1 \alpha$ and EPO was at the control level, no changes were detected (see Fig. 2, black bars).

To future examine possible antidepressant-like action of HIF-1 we performed the experiment with administration of HIF-1 inhibitor topotecan. The injection of topotecan to LH group accelerated the depressive-like behavioral symptoms in the open field test. In particular, the time of freezing was increased significantly, compared to all other experimental groups (Fig. 3). In the LH animals received topotecan injection, the freezing reactions lasted more than 4-fold longer than in LH group without additional treatments. 


\section{Discussion}

HIF-1 is a transcriptional factor, a heterodimer formed by HIF- $1 \alpha$ и HIF- $1 \beta$ subunits. Being a regulatory subunit, HIF- $1 \alpha$ is stabilized in conditions of low oxygen, e.g. hypoxia. For this reason, HIF- $1 \alpha$ is considered as an intracellular oxygen sensor [16]. Oxygen-independent mechanisms of HIF- $1 \alpha$ induction have been described, as well [17]. In contrast to HIF- $1 \alpha$, HIF- $1 \beta$ is constitutively expressed independently of conditions [18]. In normoxia, HIF- $1 \alpha$ is hydroxylated by prolyl-hydroxylases and then degraded by a cascade of modifications [19]. Prolyl-hydroxylases require oxygen for their activity and therefore are inactivated in hypoxia. As a result, HIF1 $\alpha$ is stabilized, dimerized with HIF-1 $\beta$ that leads to functional activation of HIF-1 which is translocated to the nucleus and binds to HRE (Hypoxia Response Elements) in target genes. Among main targets of HIF-1 is vascular endothelial growth factor (VEGF), glucose transporter-1 (GLUT1), enzymes of pentose phosphate pathway, and erythropoietin [20]. Although EPO is a factor responsible for erythropoiesis, its high expression has been also found in brain, where it is supposed to exert broad spectrum of neuroprotective effects independent of the erythropoiesis [9-11]. It has been well documented that administration of exogenous EPO increased neuroprotection in the experimental models of hypoxia/ischemia [21]. Due to this reason, in the present study we examined both HIF- $1 \alpha$ and EPO expression, trying to dissect possible involvement of HIF-1 and its downstream EPO-driven neuroprotective mechanisms in the antidepressant-like action of HPostC. Since HPostC includes hypoxic exposures and we believe that hypoxia is the primary conditioning factor, one could expect induction of HIF- $1 \alpha$ by the HPostC and, indeed, it has been reported in our previous studies in the hypoxic models [7]. In our recent study induction of HIF-1 was for the first time observed in non-hypoxic paradigm - an experimental model of posttraumatic stress disorder, representing one of most common stress-related anxiety disorder $[22,23]$. It is important for understanding of these findings that HIF-1 can be activated or influenced through oxygen-independent mechanisms, e.g. via growth factors, deregulated oncogenes, kinase cascades [17]. This question is still poorly studied but the role of PI3K, AKT/PKB and MAPK pathways has already been demonstrated. The profile of poststress expression of HIF- $1 \alpha$ was drastically modified by the hypoxic pre- and interconditioning, indicating its apparent involvement in the stress-protective action of mild hypoxic exposures applied before and between stresses [23].

In the present study, we report new results obtained in the experimental model of depression. The findings are in strong agreement with previous data reported for other models and indicate that HIF-1 appears to be involved in the realization of the protective HPostC effects in the model of depression, as well. Obviously, the enabled down-stream mechanism involves EPO.

The experiments with HIF-1 inhibitor further supported hypothesis on the interfering of HIF-dependent mechanisms with the pathogenetic mechanisms of depression. The fact that inhibiting of HIF-1 below the control levels worsen the state and increased severity of depression notably contributes to the understanding of apparent antidepressant-like actions of HIF-1.

According to the current theory, a key step of the pathogenetic process in depression is an impairment of glucocorticoid feedback. In this regard, important to note that HIF-1 tightly interacts with brain glucocorticoid receptors at multiple levels, staring from regulation of gene expression of each other, and up to direct protein-protein interactions in the cytosol. The functional synergy between glucocorticoid receptors and EPO has also been reported in some physiological processes [24]. Citing of these facts herein outlines possible directions for future studies aimed at investigation of HIF-1 roles in stress-protective processes that can open new avenues for therapeutic approaches in depression, both pharmaceutical and medicinal free.

In summary, the data obtained indicate that HIF-1 and its downstream target EPO appear to be involved in the protective anti-depressive mechanisms, including those activated by hypobaric hypoxic postconditioning.

\section{Additional information}

Funding. The work has been supported by RFBR No. 19-015-00336 and performed using animal resources of the SF "Pavlov Institute Biocollection Centre".

Conflict of interest. The authors declare no conflict of interest in financial or any other sphere.

\section{References}

1. Samoilov MO, Rybnikova EA, Tulkova El, et al. Hypobaric hypoxia affects rat behavior and immediate early gene expression in the brain: the corrective effect of preconditioning. Dokl Biol Sci. 2001;381:513-515. https://doi. org/10.1023/a:1013301816108.

2. Patent RUS No. 2437164/ 20.12.2011. Rybnikova EA, Samoilov MO. Sposob reabilitatsii posle gipoksii, vyzyvayushchey narusheniya funktsiy mozga $v$ modelyakh na laboratornykh zhivotnykh.

3. Rybnikova E, Vorobyev M, Pivina S, Samoilov M. Postconditioning by mild hypoxic exposures reduces rat brain injury caused by severe hypoxia. Neurosci Lett. 2012;513(1):100105. https://doi.org/10.1016/j.neulet.2012.02.019. 
4. Gamdzyk M, Makarewicz D, Slomka M, et al. Hypobaric hypoxia postconditioning reduces brain damage and improves antioxidative defense in the model of birth asphyxia in 7-day-old rats. Neurochem Res. 2014;39(1):68-75. https:// doi.org/10.1007/s11064-013-1191-0.

5. Vetrovoi OV, Rybnikova EA, Glushchenko TS, Samoilov MO. Effects of hypoxic postconditioning on the expression of antiapoptotic protein Bcl-2 and neurotrophin BDNF in hippocampal field CA1 in rats subjected to severe hypoxia. Neurosci Behav Physiol. 2015;45(4):367-370. https://doi. org/10.1007/s11055-015-0083-y

6. Vetrovoy OV, Rybnikova EA, Glushchenko TS, et al. Mild hypobaric hypoxic postconditioning increases the expression of HIF-1 $\alpha$ and erythropoietin in the CA1 field of the hippocampus of rats that survive after severe hypoxia. Neurochem J. 2014;8(2):103-108. https://doi.org/10.1134/ s1819712414020123.

7. Sarieva KV, Lyanguzov AY, Galkina OV, Vetrovoy OV. The effect of severe hypoxia on HIF1- and Nrf2-Mediated mechanisms of antioxidant defense in the rat neocortex. Neurochem J. 2019;13(2):145-155. https://doi.org/10.1134/ s1819712419020107.

8. Kodama T, Shimizu N, Yoshikawa N, et al. Role of the glucocorticoid receptor for regulation of hypoxia-dependent gene expression. J Biol Chem. 2003;278(35):33384-33391. https://doi.org/10.1074/jbc.M302581200.

9. Jelkmann W. Molecular Biology of Erythropoietin. Intern Med. 2004;43(8):649-659. https://doi.org/10.2169/internalmedicine.43.649

10. Marti HH. Erythropoietin and the hypoxic brain. J Exp Biol. 2004;207(18):3233-3242. https://doi.org/10.1242/jeb.01049.

11. Paschos N, Lykissas MG, Beris AE. The role of erythropoietin as an inhibitor of tissue ischemia. Int $J$ Biol Sci. 2008;4(3):161-168. https://doi.org/10.7150/ijbs.4.161.

12. Tringali G, Pozzoli G, Lisi L, Navarra P. Erythropoietin inhibits basal and stimulated corticotropin-releasing hormone release from the rat hypothalamus via a nontranscriptional mechanism. Endocrinology. 2007;148(10):4711-4715. https://doi.org/10.1210/en.2007-0431.

13. Seligman ME, Beagley G. Learned helplessness in the rat. J Comp Physiol Psychol. 1975;88(2):534-541. https://doi. org/10.1037/h0076430.

14. Rybnikova E, Mironova V, Pivina S, et al. Involvement of the hypothalamic-pituitary-adrenal axis in the antidepressant- like effects of mild hypoxic preconditioning in rats. Psychoneuroendocrinology. 2007;32(7):813-823. https://doi. org/10.1016/j.psyneuen.2007.05.010.

15. Hall CS. Emotional behavior in the rat. III. The relationship between emotionality and ambulatory activity. J Comp Psychol. 1936;22(3):345-352. https://doi.org/10.1037/h0059253.

16. Kaelin WG, Ratcliffe PJ. Oxygen sensing by metazoans: the central role of the HIF hydroxylase pathway. Mol Cell. 2008;30(4):393-402. https://doi.org/10.1016/j.molcel.2008. 04.009 .

17. Agani $\mathrm{F}$, Jiang B-H. Oxygen-independent regulation of HIF-1: novel involvement of PI3K/ AKT/mTOR pathway in cancer. Curr Cancer Drug Targets. 2013;13(3):245-251. https://doi.org/10.2174/1568009611313030003.

18. O'Rourke JF, Tian Y-M, Ratcliffe PJ, Pugh CW. Oxygen-regulated and transactivating domains in endothelial PAS Protein 1: comparison with hypoxia-inducible factor-1 $\alpha$. J Biol Chem. 1999;274(4):2060-2071. https://doi.org/10.1074/ jbc.274.4.2060.

19. Masson N, Willam C, Maxwell PH, et al. Independent function of two destruction domains in hypoxia-inducible factoralpha chains activated by prolyl hydroxylation. EMBO J. 2001;20(18):5197-5206. https://doi.org/10.1093/emboj/ 20.18.5197.

20. Jegalian AG, Wu H. Differential roles of SOCS family members in EpoR signal transduction. J Interferon Cytokine Res. 2002;22(8):853-860. https://doi.org/10.1089/ 107999002760274863.

21. Risau W. Mechanisms of angiogenesis. Nature. 1997;386(6626):671-674. https://doi.org/10.1038/386671a0.

22. Rybnikova EA, Baranova KA, Gluschenko TS, et al. Role of HIF-1 in neuronal mechanisms of adaptation to psychoemotional and hypoxic stress. International Journal of Physiology and Pathophysiology. 2015;6(1):1-11. https://doi. org/10.1615/IntJPhysPathophys.v6.i1.10.

23. Baranova KA, Rybnikova EA, Samoilov MO. The dynamics of $\mathrm{HIF}-1 \alpha$ expression in the rat brain at different stages of experimental posttraumatic stress disorder and its correction with moderate hypoxia. Neurochemical Journal. 2017;11(2): 149-156. https://doi.org/10.1134/s1819712417020027.

24. Lee HY, Gao X, Barrasa MI, et al. PPAR-alpha and glucocorticoid receptor synergize to promote erythroid progenitor self-renewal. Nature. 2015;522(7557):474-477. https://doi. org/10.1038/nature14326.

\section{Сведения об авторах / Information about the authors}

Михаил Юрьевич Зенько - младший научный сотрудник, Институт физиологии им. И.П. Павлова РАН, Санкт-Петербург. https://orcid.org/0000-0002-9868-0598. SPIN-код: 6632-3116. E-mail: ZenkoMY@infran.ru.

Елена Александровна Рыбникова - д-р биол. наук, заведующий лабораторией, заместитель директора, Институт физиологии им. И.П. Павлова РАН, СанктПетербург. https://orcid.org/0000-0002-8956-726X. SPINкод: 9663-4704. E-mail: RybnikovaEA@infran.ru.
Mikhail Yu. Zenko - Lab. of Regulation of Brain Neuron Functions, Pavlov Institute of Physiology RAS, Saint Petersburg, Russia. https://orcid.org/0000-0002-9868-0598. SPIN-code: 6632-3116. E-mail: ZenkoMY@infran.ru.

Elena A. Rybnikova - Lab. of Regulation of Brain Neuron Functions, Pavlov Institute of Physiology RAS, Saint Petersburg, Russia. https://orcid.org/0000-0002-8956-726X. SPIN-code: 9663-4704. E-mail: RybnikovaEA@infran.ru.

Контактное мицо / Corresponding author

\section{Михаил Юрьевич Зенько / Mikhail Yu. Zenko}

E-mail: ZenkoMY@infran.ru 